\section{In the Rainforest}

Catherine Caufield

Heinemann, 1985, $£ 10.95$

Of books on tropical forests, there is no end-at least one dozen, whether popular or professional, during the past year. Yet there is one that certainly embellishes the record. Indeed, Catherine Caufield's book is one of the liveliest and most interesting, not to say illuminating, that I have come across.

An American journalist living in London, Caufield describes her several years of intermittent travel throughout the biome, from Panama to Indonesia and from Amazonia to Australia. Hers is a personalised account of the tropical forests situation, based on conversations with scores of scientists, conservationists, foresters and exploiters of every stripe. It is the first-hand experience behind her narrative that is the main strength of Caufield's book. One gains a sense that the thing is authentic from start to finishand Caufield's deep concern for tropical forests rings strong and clear.

On the whole, this is a fine effort to portray the situation, or rather the plight, of tropical forests. Eminently readable by the lay person, and spirited in approach, the book should appeal not only to the established conservationist, butmuch more importantly-to some of the "great unconverted'. Not all conservation books can claim as much; Caufield's book certainly can.

Dr Norman Myers, Consultant in Environment and Development

\section{Marine and Coastal Protected Areas: A Guide for Planners and Managers} Rodney V. Salm, assisted by John R. Clark IUCN, Ave du Mont Blanc, CH-1196, Switzerland Copies are available for $\$ 20.00$ plus shipping costs from the above address.

The result of a Workshop on Managing Coastal and Marine Protected Areas, held in October 1982 during the World Congress on National Parks in Bali, Indonesia, this has been designed as a guide and sourcebook for the increasing number of people involved in planning either national systems of marine and coastal protected areas or individual sites. It will probably appeal to Book reviews

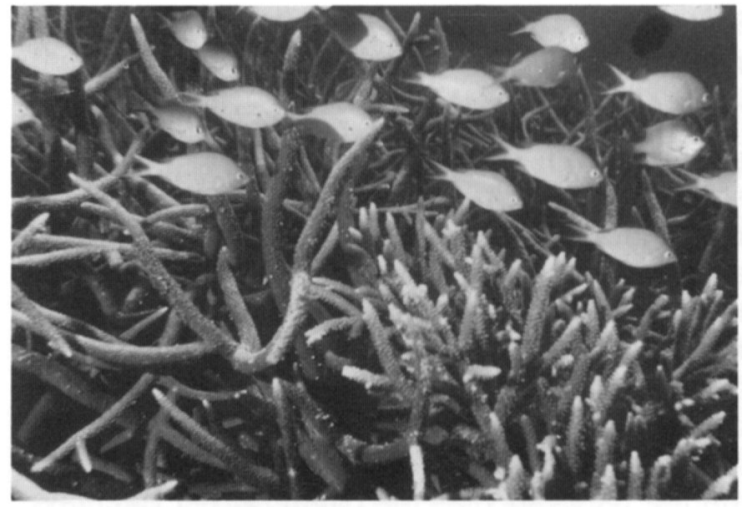

Coral reef, Indonesia (WWF/Tom Moss).

a far wider audience, including teachers, students and anyone concerned with the marine environment and its management, as it provides a broad overview of a wide range of marine conservation issues.

It is divided into three parts. The first introduces protected areas as one of the many tools for managing coastal and marine resources; despite the title, the book is based quite rightly on the fundamental premise that protected areas are only one aspect of marine conservation. The economic importance of the coast and sea, threats to marine ecosystems, and the role of protected areas are discussed, illustrated with numerous interesting facts. For example, in 1980 the total direct and imputed indirect economic benefits of the Virgin Islands National Park amounted to $\$ 23.4$ million, while its costs were only $\$ 2 \cdot 1$ million! A comprehensive bibliography will enable anyone requiring further details to follow up the examples. This section also outlines a process for planning a regional or national system of protected areas, and provides an extremely useful overview of the various international conventions and treaties which relate to the marine environment, such as the Law of the Sea.

The second part of the book considers the specific principles and techniques for planning and managing protected areas in different environments, including coral reefs, lagoons and estuaries, open seas, polar seas and small islands. An admirable aspect of this book is that it stresses the need to recognise that coastal ecosystems 